\title{
Proteomic characterisation of serum proteins from Atlantic salmon (Salmo salar L.) from an outbreak with Cardiomyopathy Syndrome
}

\section{Janina Costa}

Moredun Research Institute https://orcid.org/0000-0002-2243-0146

Jorge del Pozo ( $\sim$ Jorge.Del.Pozo@ed.ac.uk)

University of Edinburgh https://orcid.org/0000-0002-9582-1228

\section{Kevin McLean}

Moredun Research Institute

Neil Inglis

Moredun Research Institute

Philippe Sourd

Cooke Aquaculture Scotland

Andrei Bordeianu

Cooke Aquaculture Scotland

Kim D. Thompson

Moredun Research Institute https://orcid.org/0000-0003-3550-4842

\section{Research Article}

Keywords: Piscine myocarditis virus, cardiomyopathy syndrome, cardiac biomarkers, Atlantic salmon, cardiomyopathy, proteomic analysis

Posted Date: July 13th, 2021

DOI: https://doi.org/10.21203/rs.3.rs-146896/v4

License: (c) (i) This work is licensed under a Creative Commons Attribution 4.0 International License. Read Full License

Version of Record: A version of this preprint was published at Journal of Fish Diseases on July 5th, 2021. See the published version at https://doi.org/10.1111/jfd.13488. 


\section{Abstract}

Cardiomyopathy syndrome (CMS), caused by piscine myocarditis virus (PMCV), is a serious challenge to Atlantic salmon (Salmo salar L.) aquaculture. Regrettably, husbandry techniques are the only tool to manage CMS outbreaks, and no prophylactic measures are available at present. Early diagnosis of CMS is therefore desirable, preferably with non-lethal diagnostic methods, such as serum biomarkers. To identify candidate biomarkers for CMS, the protein content of pools of sera (4 fish/pool) from salmon a CMS outbreak (3 pools) and from clinically healthy salmon (3 pools) were compared using liquid chromatography-electrospray ionization-tandem mass spectrometry (LC-ESI-MS/MS). Overall, seven proteins were uniquely identified in the sera of clinically healthy fish, while twenty seven proteins were unique to the sera of CMS fish. Of the latter, 24 have been associated with cardiac disease in humans. These were grouped as leakage enzymes (creatine kinase, lactate dehydrogenase, glycogen phosphorylase and carbonic anhydrase); host reaction proteins (acute phase response proteins haptoglobin, fibrinogen, a2-macroglobulin, ceruloplasmin; and complement-related proteins); and regeneration/remodelling proteins (fibronectin, lumican and retinol). Clinical evaluation of the suitability of these proteins as biomarkers of CMS, either individually or as part of a panel, is a logical next step for the development of early diagnostic tools for CMS.

\section{Introduction}

Atlantic salmon (Salmo salar L.) is one of the most economically important aquaculture species produced in Europe. Its production is affected by several cardiac diseases of viral origin, which significantly impact on the industry's production, namely cardiomyopathy syndrome (CMS) caused by piscine myocarditis virus (PMCV), pancreas disease (PD) caused by salmonid alphavirus (SAV), and heart and skeletal muscle inflammation (HSMI) caused by piscine orthoreovirus (PRV).

Monthly mortality reports compiled by the Scottish Salmon Producers Association (SSPO) show CMS to be one of the main health issues affecting the Scottish salmon industry. Further, in Norway over 100 farms are affected with the disease each year (Fritvold et al., 2019). The mortalities may be particularly impactful, as they tend to occur during the later stages of the production cycle, although more recently it has also been reported in salmon shortly after they have been transferred to sea (Fritvold, 2016). Overall, the economic impact of CMS is substantial, with estimated losses of a single CMS outbreak cases costing up to 1.9 million $€$ in Norway (Garseth et al., 2018). Clinically, CMS can present acutely with sudden mortalities due to cardiac failure without previous clinical signs; or with chronic clinical signs including exophthalmos, cutaneous haemorrhages and raised scales with moderate protracted mortality (Ferguson et al., 1990, Brun et al., 2003). This variability in the presentation and outcomes of CMS render its management, mortality and costs mitigation very challenging in the field, especially in the absence of prophylactic strategies.

The disease was first described in Norway in 1985 (Amin et al., 1988) and subsequently termed CMS by Ferguson et al. (1990) to account for the associated pathology. In Norway, the term "acute heart failure" has also been associated with the disease. Instances of CMS have also been reported in the Faroe Islands (1984), Scotland (1997) and Ireland (2012) (Ferguson et al., 1990, Poppe et al., 2003, Rodger et al., 2014). The aetiological cause of CMS was not established until 2009, when it was confirmed to be transmissible (Bruno et al., 2009, Fritsvold et al., 2009), and caused by a virus (Løvoll et al., 2010), which was subsequently named piscine myocarditis virus or PMCV (Haugland et al., 2011). 
Piscine myocarditis virus belongs to the Totiviridae family, with small, spherical virions, approximately $50 \mathrm{~nm}$ in diameter, which consist of a non-enveloped protein shell and a dsRNA genome (Haugland et al., 2011). This genome has three open reading frames (ORF), with ORF1 encoding the major coat protein, ORF2 encoding the RNA-dependent RNA polymerase protein (RdRp) and ORF3 encoding a third protein, the function of which is not fully understood (Garseth et al., 2018). The fact that PMCV is non-culturable has been a major factor in restricting research related to both CMS and PCMV.

Diagnosis of viral diseases in aquaculture has traditionally been performed by detecting the pathogen with molecular methods or by isolating the virus in cell culture. Diagnosis of CMS is based on detection of viral RNA by quantitative polymerase chain reaction (qPCR) in infected heart tissue or by histopathology, observing pathological changes in heart tissue typical of CMS. Both methods require lethal sampling of fish, frequently at the final stages of their production cycle. This diagnostic method brings limited information when used on its own and is often used with histopathology to assess lesion severity. Further, both methods are applied to a limited number of individuals within large populations, providing rather fragmented information at a population level.

A non-lethal diagnostic method that provides an early indication of PMCV infection (i.e. before the onset of clinical signs), and is applicable to large numbers of individuals, would be desirable. Such a test would allow salmon farmers to anticipate CMS outbreaks and establish mitigation strategies to reduce or prevent its impact. Additionally, such a tool could be used as an endpoint in the genetic selection of fish for CMS resistance. Both strategies would minimise both the mortalities and economic impact of CMS.

This is a feasible proposition, as it is possible to establish early stages of disease in other animal species portraying prodromal signs of heart disease using appropriate biomarkers (Mayeux, 2004). In fact, a diverse range of serum molecules are used as biomarkers in human and other animal species to indicate the presence of cardiac disease, but the availability of such biomarkers to assess heart disease in fish is limited. More specifically, several candidates have been highlighted as potential cardiac biomarkers for fish, including creatine kinase (CK), lactate dehydrogenase (LDH), natriuretic peptides (salmon cardiac peptide cSP) and troponins. Special relevance has been placed on CK and LDH, as CK levels are elevated in pancreas disease (Rodger et al., 1991), and both CK and LDH are significantly increased in CMS and HSMI, although significant correlation with histopathological lesions was only seen for HSMI (Yousaf et al., 2012). Increased levels of CK have also been associated with muscle injury in salmon during infection by infectious salmon anaemia virus (ISAV) (Rojas et al., 2018)

As the cardiac disease biomarker repertoire research in salmon is limited, and host responses to cardiac disease have not been fully characterised in salmon, there is scope to identify additional novel serum biomarkers of heart disease in salmon using serum proteomics comparing healthy and diseased individuals. Identifying and understanding these differences is important for establishing novel biomarkers of disease (Barbosa et al., 2012). This is valuable information, as the diagnosis of a disease can require more than one biomarker, and the selection of biomarkers involves appraisal of factors such as sensitivity, specificity, costs, logistics and measurement equipment (Byrnes et al., 2018). One of the most common methods used to identify novel biomarkers is mass spectrometry (MS) of fractionated protein samples (shotgun approach) (Ahrens et al., 2010). MS-based proteomics allows identification of specific proteins from a wide range of biological samples and is capable of identifying proteins with high sensitivity within a large dynamic range, making it ideal for biomarker identification (Geyer et al., 2017). In fish, this approach has been helpful for the identification of potential biomarkers for arsenic-exposure in carp (Labeo rohita) (Banerjee et al., 2017) or for bitumen-exposure in Pacific salmon (Onchorhychus nerka) (Alderman et al., 2017). 
Here we examine the differential expression of proteins in the serum of field samples from a confirmed CMS outbreak compared to that of clinically healthy fish, analysed using liquid chromatography-electrospray ionization/tandem mass spectrometry (LC-ESI-MS/MS), in an attempt to identify putative biomarker candidates that may be further developed to allow early diagnosis of this devastating viral disease of farmed Atlantic salmon.

\section{Materials And Methods}

\subsection{Biological samples}

Blood was collected from Atlantic salmon at two marine production sites in Scotland. One site had an on-going CMS outbreak (CMS + site) and the other site was classified as a CMS-free farm (control site), with no previous history of the disease. Blood was collected from 44 Atlantic salmon from one pen on the CMS+ site and from 12 at the control site. The blood was allowed to clot at ambient temperature and serum was collected within $3 \mathrm{~h}$ post sampling, by centrifuging the blood for $3 \mathrm{~m}$ at $2680 \mathrm{xg}$ (SciSpin mini-centrifuge). The serum was immediately aliquoted and stored at $-20^{\circ} \mathrm{C}$ until transferred to the lab and storage at $-80^{\circ} \mathrm{C}$.

The disease status of fish at each farm site was assessed by gross pathology, cardiac histopathology, and PMCV specific RT-qPCR (heart and/or serum). Gross pathology and histopatholohy were conducted using standard methods, and the RT-qPCR was provided by Pharmaq Analytiq (Bergen, Norway). Fish were classified as CMS+ if at least two of the disease diagnose methods (gross pathology, histology and RT -qPCR) were consistent with CMS and PCMV infection respectively, and as CMS- if this was not the case. Of the $44 \mathrm{CMS}+$ sera samples, 12 (4 fish $\times 3$ pools) were selected for analysis by proteomics. The hearts of 8 of these $12 \mathrm{CMS}+$ fish (Table 1) were not analysed by histology or RT-qPCR since the gross pathology was so severe that these hearts were used in a parallel study that aimed toisolate PMCV by cell culture.

\subsection{Sodium dodecyl sulphate polyacrylamide gel electrophoresis (SDS-PAGE)}

Pools of sera were used to reduce variability between individual fish. Three CMS+ sera pools $(\mathrm{CMS}+11, \mathrm{CMS}+22$, ICMS+ 3; n=4 CMS+ fish/pool) and three CMS- sera pools (CMS- 1, CMS- 2, CMS- 3; n=4 CMS- fish/pool) were prepared for analysis. The proteins were separated by electrophoresis, for which sera were denatured with lithium dodecyl sample buffer (NuPAGE LDS sample buffer, Invitrogen, ThermoFisher Scientific, Renfrew, UK), 50 mM dithiothreitol (DTT) (NuPAGE reducing agent, Invitrogen) and heating the sample to $70^{\circ} \mathrm{C}$ for $10 \mathrm{~min}$. The average protein concentration of the CMS+ sera was $29.6( \pm 6.2) \mathrm{mg} \mathrm{ml}^{-1}$ and $72.8( \pm 5.6) \mathrm{mg} \mathrm{ml}^{-1}$ for the non-infected sera. The former was diluted 1:1 and the latter 1:15 to have similar protein profiles resolved on the gel. The samples were loaded (20 L per lane) onto a pre-casted 12\% NuPAGE Bis-Tris Mini Gels, using SeeBlue Plus2 prestained standards (Invitrogen, ThermoFisher Scientific, Renfrew, UK) as a molecular weight reference. The gels were run on an XCell SureLock Mini-Cell electrophoresis system (ThermoFisher Scientific, Renfrew, UK) for 45 min at $200 \mathrm{~V}$ using NuPAGE MES SDS running buffer supplemented with NuPAGE antioxidant. The resolved proteins were stained with SimplyBlue Safe Stain (Invitrogen) for $1 \mathrm{~h}$ and de-stained with deionised water for a further $1 \mathrm{~h}$.

\subsection{MS/MS}


Liquid chromatography-electrospray ionization-tandem mass spectrometry (LC-ESI-MS/MS) was used to analyse the gels containing the protein profiles. Each stained gel lane (3 CMS+ and 3 CMS- sera) was removed from the gel, and a series of equal gel slices of $2.5 \mathrm{~mm}$ deep, from top to bottom were made. The slices underwent in-gel de-staining, reduction, alkylation and trypsinolysis as described (Shevchenko et al., 1996). An Ultimate 3000 nanoHPLC system (Dionex) with a WPS-3000 well-plate micro auto sampler, a FLM-3000 flow manager and column compartment, a UVD-3000 UV detector, an LPG-3600 dual-gradient micropump and an SRD-3600 solvent rack controlled by Chromeleon ${ }^{\text {TM }}$ chromatography software was used to perform the liquid chromatography analysis. A micro-pump with a flow rate of $246 \mu \mathrm{min}^{-1}$ was used in combination with a cap-flow splitter cartridge, affording a $1 / 82$ flow split and a final flow rate of $3 \mu \mathrm{min}^{-1}$ through a $5 \mathrm{~cm} \times 200 \mathrm{~mm}$ ID monolithic reversed phase column (Thermo) maintained at $50^{\circ} \mathrm{C}$. The samples $(4 \mathrm{ml})$ were injected directly onto the column. Elution of peptides was achieved by the application of a 15 min linear gradient from $8-45 \%$ solvent B ( $80 \%$ acetonitrile, $0.1 \%$ (w/v) formic acid) and directed through a 3ml UV detector flow cell. LC was interfaced directly with a 3-D high capacity ion trap mass spectrometer (amaZon-ETD, Bruker Daltonics) via a low-volume (50 ml min-1 maximum) stainless steel nebuliser (Agilent) and ESI. The parameters for tandem MS analysis were based on those described previously by Batycka et al. (2006).

\subsection{Data mining}

After importing the deconvoluted MS/MS data in .mgf (Mascot Generic Format) into ProteinScape ${ }^{\mathrm{TM}}$ V3.1 (Bruker Daltonics), proteomics data analysis software, Mascot ${ }^{\mathrm{TM}} \mathrm{V} 2.3$ (Matrix Science) search algorithm was used for downstream database mining of the annotated Atlantic salmon genome sequence. Protein Search" feature of ProteinScape $^{\text {TM }}$ was used to establish the protein content of each individual gel slice, whereas the "Protein Extractor" feature was used to compile the protein content of all gel slices into a single result file. The guidelines established by Taylor et al. (2005) were used to set Mascot search parameters, and to this end, fixed (carbamidomethyl "C") and variable (oxidation "M" and deamidation "N,Q") modifications were selected along with peptide (MS) and secondary fragmentation (MS/MS) tolerance values of $0.5 \mathrm{Da}$ whilst allowing for a single $13 \mathrm{C}$ isotope. Molecular weight search (MOWSE) scores attained for individual protein identifications were inspected manually and a list of significant protein were prepared. The proteins were considered significant only if

a) two peptides were matched for each protein, and b) each matched peptide contained an unbroken "b" or " $y$ " ion series represented by a minimum of four contiguous amino acid residues.

\subsection{Data analysis}

Proteins identified in the three CMS+ pools were compared in order to select proteins common to all infected samples pools. The same procedure was applied to select proteins common to all CMS- pools. The two sets of selected CMS+ and CMS- proteins were then compared, and a list of unique proteins produced for each of them. The functional annotation and mapping of unique protein sequences were performed using Blast2Go (Götz et al., 2008). Briefly, the protein sequences were blasted with NCBI Blast Service (QBlast), then the proteins were run through IntrePro to classify them by family and to identify main domains; the final functional annotation was performed by mapping homologue sequences and annotating them with Gene Ontology databases. 


\section{Results}

\subsection{Sample diagnostics}

Forty four fish were sampled from a pen in a farm with a known ungoing CMS outbreak. The sera werecollected from moribund fish displaying macroscopic lesions consistent with CMS (e.g. exophthalmia, ventral skin haemorrhages, raised scales), which had PMCV RNA in tissues and/or serum. Conversely, all 12 CMS- fish were clinically normal, devoid of macroscopic lesions and were negative by the RT-qPCT and histopatholohy (Suppl. Table 1).

\subsection{SDS gel electrophoresis}

When the pools of sera were resolved by SDS-PAGE electrophoresis (Figure 1), similar protein profiles were observed between the three pools of sera from CMS+ fish and between the three pools of sera from CMS- fish. Conversely, clear differences were observed in the protein profiles between CMS+ sera and CMS- sera, with CMS+ sera presenting with a visibly higher number of protein bands between $49-28 \mathrm{k} \mathrm{Da}$ and $28-14 \mathrm{kDa}$.

\subsection{Common proteins within pool types (CMS+ and CMS-)}

The data mining of the peptides obtained with LC-ESI-MS/MS analysis of the three CMS+ pools (Inf 1-3), identified 136, 136 and 158 protein sequences respectively, with 85 proteins found in common between the three pools. Of these 85 proteins, 13 were complement-related, 11 were haemoglobin-related, and there were 5 apolipoprotein, 4 alpha - 2-macroglobulin, 4 fibrinogen, 3 fibronectin, 3 fibronexin, 2 hemopexin, 2 lipocalin, 2 retinol binding, 2 serum albumin and 2 serotransferrin proteins. Proteins for which only one sequence was identified included: pyruvate kinase, creatine kinase, C-reactive protein, haptoglobulin-like, L-lactate dehydrogenase, angiotensinogen, myosin and keratin.

For CMS- pools (Ctr 1-3), 88, 97 and 98 protein sequences were identified, respectively Of these, 57 protein sequences were common to all three pools, with 13 being complement-related, 7 haemoglobin-related, 4 apolipoprotein, 3 alpha-2-macroglobulin, 2 hemopexin, 2 serotransferrin, 2 serum-albumin, 2 protein LEG1 homolog-2 and 2 fibronectin. Proteins with only one sequence identified were angiotensinogen, C-reactive protein, fibrinogen, myosin and lipocalin.

\subsection{Differences in protein content between pool types (CMS+ and CMS-)}

When the lists of proteins common to CMS+ and CMS- pools were compared, 37 protein sequences were found to be unique to CMS+ pools (Table 2 and Suppl. Table 2) and 10 unique to CMS- pools (Table 3 and Suppl. Table 3).

Of the 37 proteins unique to CMS+ pools, $8(21.6 \%)$ were identified with over $60 \%$ sequence coverage in the 3 CMS+ pools, where $34(92 \%)$ had a molecular weight below $100 \mathrm{kDa}$. After sequence analysis of proteins exclusively present in $\mathrm{CMS}+$ pools, there were three instances of several sequences pertaining to the same protein: 5 were identified as haemoglobin (i.e. $\alpha=2, \beta=3), 3$ as fibrinogen $(\alpha=1, \beta=1, \gamma=1), 2$ as apolipoprotein-Eb-like and 2 
as retinol-binding. Therefore, 29 protein sequences unique to CMS+ pools were then considered for subsequent analysis. As for the sequence analysis of the 10 proteins exclusively present in CMS- pools, there was one instance of two sequences pertaining to the same protein: protein LEG1 homolog. Therefore, 9 protein sequences unique to CMS- pools were considered for subsequent analysis.

\section{Discussion}

Cardiomyopathy syndrome is a viral disease of Atlantic salmon, which causes severe chronic cardiac lesions in various regions of the heart tissues. Early diagnosis and even prognosis of CMS is desirable for its control, and this could be potentially achieved by detecting and quantifying serum protein biomarkers.

In human medicine, diagnosis of cardiac diseases such as myocardial infarction (MI) and heart failure (HF), is heavily based on individual profiling of protein biomarkers (Smith et al., 2017), which allow diagnosis of subclinical/prodromic presentations (Mayeux, 2004). As defined by the Biomarkers Definition Working Group (2001), "a biological marker or biomarker is a characteristic that is objectively measured and evaluated as an indicator of normal biological processes, pathogenic processes, or pharmacologic responses to a therapeutic intervention". The use of biomarkers has been central in the development of accurate prognosis and diagnosis of human disease. In order to identify potential biomarkers, several methodologies have been applied, with particular emphasis on proteomic analysis of serum. Proteomic analysis presents the entire set of proteins expressed by an individual, cell or organ at a given time, including post-transcriptional, post-translational and protein complexes (Ahrens et al., 2010). This analysis is usually performed using liquid chromatography-mass spectrometry (LC-MS/MS), a qualitative technique capable of analysing complex samples such as serum (Zhou et al., 2020). The scope of this work was, in a preliminary way to study if it was possible to observe proteomic differences between CMS infected and non-infected fish. In this study, we used a shotgun approach to identify potential biomarkers for the disease (Ahrens et al., 2010), by comparison of CMS+ (diseased) and CMS- (clinically healthy) sera. This method is faster and more affordable than other proteomics such as Mascot, and within its limitations in sensitivity and depth proved to be useful by permitting to highlight the proteomic differences between CMS+ and CMS- fish. An analytical approach involving digestion by a proteolytic enzyme to create a complex peptide mixture (bottom-up approach) was chosen, since it offers several advantages in terms of its reproducibility and sensitivity when analysing complex serum samples (Barbosa et al., 2012).

The proteome analysis of fish serum has been performed with pool samples ((Li et al., 2016, Alderman et al., 2017). Due to an expected large individual variability the samples were analysed as pools of sera ( $\mathrm{n}=4 \mathrm{fish} / \mathrm{pool})$. The use of serum pools makes impossible to access individual characteristics such as viral load or clinical state. However since the aim of this study was the proteomics characterisation of CMS+ and CMS- as a group and not individual characterisation or correlation with disease status, the use of serum pools is suitable. Only common proteins to each pool type (CMS+/CMS-) were taken forward for analysis. The three CMS+ pools, with 136, 136 and 158 proteins identified, just 85 were common between the 3 pools. This considerable low level of common proteins was expected when using a complex biological sample as serum, a relatively low sensitive method and the application of the strict validation regime used. In our study, twenty-seven proteins were uniquely identified in $\mathrm{CMS}+$ sera and seven proteins were unique to CMS- sera. Of the proteins unique to CMS+ sera, the majority have been previously associated with cardiac disease (24 proteins), and the remainder are involved in cell structure ( 2 proteins) or sexual endocrine function (1 protein). Further, included in the list are previously described myocardial injury biomarkers, such as creatine kinase, L-lactate dehydrogenase, glycogen phosphorylase and carbonic 
anhydrase (Kemp et al., 2004). These are all cardiomyocyte cytoplasmic enzymes found in healthy cardiomyocytes that leak into the serum during cardiomyocyte damage (leakage enzymes). Other candidate biomarkers were seen, and all candidates are summarized in Figure 2, which includes the aforementioned leakage proteins, but also proteins involved in host reaction to disease, regeneration/remodelling and energy metabolism.

This study did not identify well known cardiac biomarkers such as troponins. This is due to a combination between serum being an extreme complex biological sample, with proteins present over a huge dynamic range, and the sensitivity of the technique employed. A more comprehensive characterisation of serum proteomes would require the use of depletion methods or extensive fraction techniques, which was not under the scope of this study.

\subsection{Leakage enzymes}

Creatine kinase (CK), L-lactate dehydrogenase (L-LDH), Glycogen phosphorylase (GP) and Carbonic anhydrase (CA) are all used as direct or indirect myocardial injury biomarkers in other species. However, their use is not restricted to myocardial injury, as they are also detected in serum during skeletal muscle and liver disease or even during extreme exercise (Lippi et al., 2013, Bodor, 2016). This limits their usefulness as specific biomarkers of cardiac disease when used on their own, but this limitation can be overcome if they are part of biomarker panels.

Creatine kinase is a dimer consisting of subunits $\mathrm{M}$ and/or $\mathrm{B}$, which combine to form isomers CK-BB, CK-MM and CK-MB. In humans, CK-MB is found almost exclusively in the myocardium, and high levels in serum is a highly specific and sensitive indicator of myocardial cell wall injury (Cabaniss, 1990). In our study a CK-M type protein was identified in CMS+ sera. As CMS does not cause skeletal muscle lesions, it is very likely that the CK-M identified was of cardiac origin. The potential of using CK to diagnose piscine disease was first suggested by Rodger et al. (1991) for pancreas disease (PD), a viral disease causing heart and muscle lesions in Atlantic salmon. This was supported by serum proteomics by Braceland et al. (2013), who found a correlation between serum CK levels and PD-associated lesions. In CMS, elevation of CK serum levels has been noted, but this is not correlated with CMS cardiac histopathology scores (Yousaf et al., 2012). This suggests that there may be a factor other than CMS lesion severity driving CK serum levels in CMS diseased fish.

L-lactate dehydrogenase has two subunits and five isoforms. It is an enzyme involved in energy production (i.e. converts lactate to pyruvate and back, and NAD to NADH and back), and for this reason is found in almost all cell types. Consequently, this enzyme has been used as a human and veterinary biomarker for a wide range of diseases causing tissue damage, including myocardial, hepatic, skeletal muscle and renal disease, as well as haematological and neoplastic disorders (Khan et al., 2020, Klein et al., 2020). In fish, LDH has been used in toxicological, and infectious disease assessment settings in a range of species other than Atlantic salmon (Oliveira et al., 2013, Ajima et al., 2015, Elia et al., 2017, Kumar et al., 2018). Importantly, Yousaf et al. (2012) recorded LDH serum elevation in CMS in Atlantic salmon, which as with CK, was not correlated with CMS cardiac lesion scores.

Glycogen phosphorylase (GP) is an enzyme that breaks glycogen into glucose subunits. Its isoenzymes are found in muscle, liver and brain (David et al., 1986). For this reason, it has been extensively used as a biomarker in injury to those organs. Two settings for its use in human medicine are as a biomarker of cardiac injury for cardiotoxicity 
evaluation (Zhu et al., 2018) and diagnosis of acute myocardial injury (Lippi et al., 2013). In fish, an increase in serum GP has been noted in starved Atlantic salmon (Sundby et al., 1991) and in Claria bratrachus, it has been suggested as a biomarker of cypermethrin toxicity (Begum, 2009).

Carbonic anhydrases (CA) are a family of cytoplasmic metalloenzymes, with fourteen isoenzymes that catalyze the reversible conversion between carbon dioxide and water to bicarbonate and hydrogen ions. They are therefore ubiquitous in the body and are involved in acid-base homeostasis and fluid balance (Lindskog, 1997). All CA isoenzymes have been used as biomarkers of neoplastic, infectious, parasitic and degenerative disease affecting a wide range of organ systems (Zamanova et al., 2019). In the human cardiac disease context, the ratio of CA III and serum myoglobin has been used to identify post-surgical cardiac injury, as myoglobin is present in both heart and skeletal muscle and CA III is only present in skeletal muscle (Vuotikka et al., 2003). Interestingly, recent work has revealed membrane bound CA IV in all cardiac chambers of coho salmon (Oncorhynchus kisutch), which is believed to facilitate oxygen unloading from venous blood, therefore facilitating oxygenation of a heart without coronary circulation (Alderman et al., 2016). Regrettably, in our study, the serum CA isotype detected was not recognized by the analysis, and further characterization of circulating CA in CMS fish would be required to evaluate its biomarker potential.

\subsection{Host reaction proteins}

This subgroup of proteins unique to CMS+ sera includes acute phase response proteins (haptoglobin, fibrinogen, a2-macroglobulin, ceruloplasmin) and complement-related proteins (factor B and serine protease-like). Acute phase proteins are proteins that increase (positive) or decrease (negative) in response to inflammation (Latimer, 2011). The complement system is part of the innate immune system, and its effector functions include recruitment and activation of inflammatory cells and opsonization and lysis of microbes (Kumar et al., 2014). These host response proteins are interpreted as the result of a systemic response to disease, and could have potential as candidate biomarkers of disease in general and in CMS as part of biomarker panels.

Haptoglobin rapidly binds to haemoglobin after haemolysis and tissue damage events, protecting the tissues and cells from oxidative damage (Andersen et al., 2012). It has been used as a diagnostic biomarker for neurological disease, diabetes, certain cancers and bovine mastitis (Nirala et al., 2020). It is also an important biomarker for humans at risk of acute MI, stroke and HF (Holme et al., 2009, Haas et al., 2011). In fish viral disease, Cordero et al. (2017) found variability in haptoglobin expression depending on the fish and viral species. In gilthead seabream (Sparus aurata) haptoglobin was up-regulated in lymphocystis disease virus infection (LCDV), but down-regulated in nervous necrosis virus infection (NNV) - to which they are resistant. Conversely, in European seabass (Dicentrarchus labrax) - which is susceptible to NNV- haptoblobin was up-regulated during NNV infection. Notably, levels of haptoglobin were also seen to be up-regulated in Atlantic salmon infected with sea lice Caligus rogercresseyi (Valenzuela-Muñoz et al., 2017). The presence of haptoglobin in CMS+ sera in our study, suggests that haptoglobin is a candidate biomarker for CMS in Atlantic salmon.

An acute phase protein used to predict stroke and $\mathrm{MI}$ in human patients, fibrinogen, was also identified in CMS+ sera. Fibrinogen is an acute phase protein (Jain et al., 2011) and its GO biological function is assigned as "platelet 
activation, blood coagulation and fibrin clot formation”. Its presence in CMS+ sera is not surprising, as CMS lesions feature intraluminal cardiac thrombosis and cutaneous haemorrhage (Garseth et al., 2018), and all of these may indicate a coagulopathy. This idea is also supported by the presence of kininogen and a serine protease-like protein in CMS+ sera. Kininogens are the precursor of kinins, which act as inflammatory mediators, but also are involved in the contact phase of the clotting cascade (Weisel et al., 1994). In fact, increased levels of kininogen in plasma and tissues are linked with injury, inflammation, myocardial infarction, and diabetes (Wong, 2016). The superfamily of serine proteases is involved in a range of processes, including such as blood coagulation, platelet activation, fibrinolysis and thrombosis, inflammation, coagulation and haemorrhaging (Wu et al., 2005, Patel, 2017). In our study, gene oncology assigned the molecular function of the serine protease-like protein as "serine-type endopeptidase activity", which is synonymous to "blood coagulation factor activity" (http://geneontology.org/, accessed 01/06/2020).

The overall picture of coagulopathy in CMS+ fish is also complemented by the presence of Alpha-2 macroglobin $\left(\mathrm{a}_{2}-\mathrm{M}\right)$ in CMS+ serum, as this is an inhibitor of thrombin and plasmin (de Boer et al., 1993). The cardiac isoform of this protein causes cardiac hyperthrophy, and is used as an early diagnostic marker of cardiac diseases in patients with HIV and diabetes (Ramasamy et al., 2006, Yoshino et al., 2019). The presence of higher levels of cardiac isoform $\mathrm{a}_{2}-\mathrm{M}$ is beneficial during the early onset of myocardial damage associated with diabetes, due to its protease inhibitor function and antioxidant effect (Soman et al., 2011). When Atlantic salmon were pre-treated with $\mathrm{a}_{2}-\mathrm{M}$, then injected with a serine protease from Aeromonas salmonicida, $\mathrm{a}_{2}-\mathrm{M}$ was found to inhibit the serine protease by preventing the pro-coagulant effect of the enzyme (Salte et al., 1993).

Ceruloplasmin carries copper and oxidizes iron, facilitating its inclusion in transferrin (Hellman et al., 2002). It has been detected in high levels in patients with myocardial infarction, heart failure, ischemic and non-ischemic cardiomyopathy, coronary heart disease, artheriosclerosis or angina (Reunanen et al., 1992, Mänttäri et al., 1994, Ziakas et al., 2009, Dadu et al., 2013, Xu et al., 2013). In fact, high levels of ceruloplasmin correlate with the severity of cardiac failure and non-ischemic cardiomyopathy (Xu et al., 2013, Andreasova et al., 2018). In fish, this protein has been investigated as a possible biomarker of bacterial resistance in fish (Sahoo et al., 2013). This is possibly due to its role in reducing iron availability to the bacteria.

Protein complement factor B, usually know as factor B, is a serine protease (Hourcade et al., 1998), part of the alternative complement system pathway (Kulkarni et al., 2008, Ricklin et al., 2010). Its presence in CMS+ serum is not surprising, as a systemic inflammatory response is to be expected during PCMV infection, where the complement cascade is likely to promote inflammatory cell recruitment and activation, and destruction of infected cardiomyocytes.

\subsection{Regeneration/remodelling}

Cardiomyopathy syndrome in Atlantic salmon frequently presents as a chronic cardiac lesion that leads to acute cardiac failure (Garseth et al., 2018). This chronicity is aligned with the findings of our study, where several proteins associated with regeneration and remodelling were unique to $\mathrm{CMS}+$ serum. 
Fibronectin was uniquely identified in CMS+ serum. One form of fibronectin (FN1) is a major glycoprotein in the extracellular matrix and is critical in cell adhesion, differentiation, migration, and growth (Pankov et al., 2002). This is a protein known to be actively involved in epicardium regeneration in zebrafish after cardiac injury (Wang et al., 2013). Importantly, there is evidence that cardiac regeneration occurs in CMS+ Atlantic salmon (Garseth et al., 2018). The second form of fibronectin (FN2) is presented on the cell surface and was first identified in zebrafish, and then later in other species of fish, mice and humans (Liu et al., 2002, Liu et al., 2003). Bearzoti et al. (1999) suggested that fibronectin mediates in the entry of fish rhabdoviruses into cells. It was subsequently shown that FN2 can mediate the attachment and entry of infectious hematopoietic necrosis virus (a piscine rhabdovirus) into cells (Liu et al., 2002). It is unclear which fibronectin form, FN1 or FN2, was identified in the present study, since its identity is based on a predicted protein in a computer-annotated Atlantic salmon genome.

Lumican is an extracellular matrix proteoglycan that is required for organisation of the collagenous matrix (Chakravarti et al., 1998), and is also present in CMS+ serum. Engebretsen et al. (2013) noted that cardiac lumican levels are higher in human patients with heart failure; and its role in cardiac remodelling post pressure overload has been recorded in a mouse model (Mohammadzadeh et al., 2019). In fish, lumican has been identified in the skin mucus of carp (Cyprinus carpio) infected with Ichthyophthirius multifiliis (Saleh et al., 2018). We hypothesize that the presence of this protein in $\mathrm{CMS}+$ serum is associated with cardiac remodelling and may be an indicator of chronicity in this setting.

A retinol-binding protein was also present in $\mathrm{CMS}+$ serum (retinol is also known as vitamin A). In zebrafish, cardiomyocytes induce the expression of a retinoic acid-synthesizing enzyme in response to injury, promoting cardiomyocyte proliferation, and subsequent heart regeneration (Kikuchi et al., 2011). Further, lipocalin was also identified, which among other roles is involved in transmembrane transport of retinol into cells through the plasma retinol-binding protein (RBP) (Flower, 1996). In the study of Yndestad et al. (2009), high levels of neutrophil gelatinase-associated lipocalin (NGAL or lipocalin-2), were observed in the serum of patients with acute MI/HF and chronic HF, which led to their suggestion as HF candidate biomarkers. The identification of these two proteins in CMS+ serum suggests the possibility of cardiac regeneration in CMS diseased fish, a topic for further investigation.

In conclusion, this proteomic study has provided an insight into the proteins present in Atlantic salmon serum with CMS. The proteins unique to CMS+ serum include well-documented cardiac disease biomarkers, inflammatory biomarkers (acute phase proteins/complement), and candidate biomarkers for tissue remodelling/regeneration. The panel of proteins obtained suggests shotgun LC-MS/MS has a genuine potential as a rapid, low cost technique for preliminary identification of candidate cardiac disease biomarkers of viral disease of farmed Atlantic salmon. Fuller assessment of the proteins identified here is need to establish their usefulness as biomarkers to assess the disease status of CMS-affected Atlantic salmon.

\section{Declarations}

\section{Acknowledgements}

The authors would like to thank Cooke Aquaculture Scotland and Scottish Aquaculture Innovation Centre (SAIC) for sponsoring this study.

Page $11 / 26$ 


\section{Data availability}

The raw proteomic data can be shared if requested. All the analysed data are compiled and presented in the tables in the manuscript and in the supplemented data file.

\section{Conflict of Interest}

The authors declare no conflict of interest.

\section{References}

<Gaggin_2010_Cardiac Biomarkers and Heart Failure - American College of Cardiology.pdf>.

Ahrens, C. H., Brunner, E., Qeli, E., Basler, K. \& Aebersold, R. (2010). Generating and navigating proteome maps using mass spectrometry. Nature Reviews Molecular Cell Biology, 11, 789-801. http:\\doi.org/10.1038/nrm2973.

Ajima, M. N. O., Ogo, O. A., Audu, B. S. \& Ugwoegbu, K. C. (2015). Chronic diclofenac (DCF) exposure alters both enzymatic and haematological profile of African catfish, Clarias gariepinus. Drug and Chemical Toxicology, 38, 383-390. http:\\doi.org/10.3109/01480545.2014.974108.

Alderman, S. L., Harter, T. S., Wilson, J. M., Supuran, C. T., Farrell, A. P. \& Brauner, C. J. (2016). Evidence for a plasma-accessible carbonic anhydrase in the lumen of salmon heart that may enhance oxygen delivery to the myocardium. Journal of Experimental Biology, 219, 719-724. http:\\doi.org/10.1242/jeb.130443.

Alderman, S. L., Dindia, L. A., Kennedy, C. J., Farrell, A. P. \& Gillis, T. E. (2017). Proteomic analysis of sockeye salmon serum as a tool for biomarker discovery and new insight into the sublethal toxicity of diluted bitumen. Comparative Biochemistry and Physiology Part D: Genomics and Proteomics, 22, 157-166. http:\\doi.org/10.1016/j.cbd.2017.04.003.

Amin, A. B. \& Trasti, J. (1988). Endomyocarditis in atlantic salmon in Norwegian seafarms. A case report. Bulletin of European Association of Fish Pathologists, 8, 70-71.

Andersen, C. B., Torvund-Jensen, M., Nielsen, M. J., de Oliveira, C. L., Hersleth, H. P., Andersen, N. H., Pedersen, J. S., Andersen, G. R. \& Moestrup, S. K. (2012). Structure of the haptoglobin-haemoglobin complex. Nature, 489, 456459. http:\\doi.org/10.1038/nature11369.

Andreasova, T., Vondrakova, D., Sedlackova, L., Dvorak, J., Taborsky, L., Neuzil, P. \& Malek, F. (2018). Evaluation of ceruloplasmin - a potential biomarker in chronic heart failure. Journal of Clinical \& Experimental Cardiology, 09. http:\\doi.org/10.4172/2155-9880.1000601.

Banerjee, S., Mahanty, A., Mohanty, S., Mazumder, D. G., Cash, P. \& Mohanty, B. P. (2017). Identification of potential biomarkers of hepatotoxicity by plasma proteome analysis of arsenic-exposed carp Labeo rohita. Journal of Hazardous Materials, 336, 71-80. http:\Idoi.org/10.1016/j.jhazmat.2017.04.054. 
Barbosa, E. B., Vidotto, A., Polachini, G. M., Henrique, T., de Marqui, A. B. T. \& Helena Tajara, E. (2012). Proteomics: methodologies and applications to the study of human diseases. Revista da Associação Médica Brasileira (English Edition), 58, 366-375. http:\\doi.org/10.1016/s2255-4823(12)70209-6.

Batycka, M., Inglis, N. F., Cook, K., Adam, A., Fraser-Pitt, D., Smith, D. G. E., Main, L., Lubben, A. \& Kessler, B. M. (2006). Ultra-fast tandem mass spectrometry scanning combined with monolithic column liquid chromatography increases throughput in proteomic analysis. Rapid Communications in Mass Spectrometry, 20, 2074-2080. http:\\doi.org/10.1002/rcm.2563.

Bearzotti, M., Delmas, B., Lamoureux, A., Loustau, A.-M., Chilmonczyk, S. \& Bremont, M. (1999). Fish Rhabdovirus Cell Entry Is Mediated by Fibronectin. Journal of Virology, 73, 7703-7709. http:\\doi.org/10.1128/jvi.73.9.77037709.1999.

Begum, G. (2009). Enzymes as biomarkers of cypermethrin toxicity: response of Clarias batrachus tissues ATPase and glycogen phosphorylase as a function of exposure and recovery at sublethal level. Toxicology Mechanisms and Methods, 19, 29-39. http:\\doi.org/10.1080/15376510802205650.

Bodor, G. S. (2016). Biochemical markers of myocardial damage. Electronic Journal of the International Federation of Clinical Chemistry and Laboratory Medicine, 27, 95-112.

Braceland, M., Bickerdike, R., Tinsley, J., Cockerill, D., McLoughlin, M. F., Graham, D. A., Burchmore, R. J., Weir, W., Wallace, C. \& Eckersall, P. D. (2013). The serum proteome of Atlantic salmon, Salmo salar, during pancreas disease (PD) following infection with salmonid alphavirus subtype 3 (SAV3). Journal of Proteomics, 94, 423-436. http:\\doi.org/10.1016/j.jprot.2013.10.016.

Brun, E., Poppe, T., A., S. \& Jarp, J. (2003). Cardiomyopathy syndrome in farmed Atlantic salmon Salmo salar. occurrence and direct financial losses for Norwegian aquaculture Diseases of Aquatic Organisms, 56, $214-247$.

Bruno, D. W. \& Noguera, P. A. (2009). Comparative experimental transmission of cardiomyopathy syndrome (CMS) in Atlantic salmon Salmo salar. Diseases of Aquatic Organisms, 87, 235-242. http:\\doi.org/10.3354/dao02129.

Byrnes, S. A. \& Weigl, B. H. (2018). Selecting analytical biomarkers for diagnostic applications: a first principles approach. Expert Review of Molecular Diagnostics, 18, 19-26. http:\\doi.org/10.1080/14737159.2018.1412258.

Cabaniss, C. D. 1990. Creatine Kinase. In Clinical methods: The history, physical, and laboratory examinations, Walker, H.K., Hall, W.D. \& Hurst, J.W. (Eds.) 3 Ed. Chapter 32. Butterworths: Boston. Available from: https://www.ncbi.nlm.nih.gov/books/NBK352/

Chakravarti, S., Magnuson, T., Lass, J. H., Jepsen, K. J., LaMantia, C. \& Carroll, H. (1998). Lumican regulates collagen fibril assembly: skin fragility and corneal opacity in the absence of lumican. Journal of Cell Biology, 141, 1277-86. http:\\doi.org/10.1083/jcb.141.5.1277.

Cordero, H., Li, C. H., Chaves-Pozo, E., Esteban, M. Á. \& Cuesta, A. (2017). Molecular identification and characterization of haptoglobin in teleosts revealed an important role on fish viral infections. Developmental \& Comparative Immunology, 76, 189-199. http:\\doi.org/https://doi.org/10.1016/j.dci.2017.06.006. 
Dadu, R. T., Dodge, R., Nambi, V., Virani, S. S., Hoogeveen, R. C., Smith, N. L., Chen, F., Pankow, J. S., Guild, C., Tang, W. H. W., Boerwinkle, E., Hazen, S. L. \& Ballantyne, C. M. (2013). Ceruloplasmin and heart failure in the Atherosclerosis Risk in Communities study. Circulation Heart Failure, 6, 936-943.

http:\Idoi.org/10.1161/CIRCHEARTFAILURE.113.000270.

David, E. S. \& Crerar, M. M. (1986). Quantitation of muscle glycogen phosphorylase mRNA and enzyme amounts in adult rat tissues. Biochimica et Biophysica Acta (BBA) - General Subjects, 880, 78-90.

http:\\doi.org/https://doi.org/10.1016/0304-4165(86)90122-4.

de Boer, J. P., Creasey, A. A., Chang, A., Abbink, J. J., Roem, D., Eerenberg, A. J., Hack, C. E. \& Taylor, F. B., Jr. (1993). Alpha-2-macroglobulin functions as an inhibitor of fibrinolytic, clotting, and neutrophilic proteinases in sepsis: studies using a baboon model. Infection and immunity, 61, 5035-5043. http:\\doi.org/10.1128/IAI.61.12.50355043.1993.

Elia, A. C., Magara, G., Righetti, M., Dörr, A. J., Scanzio, T., Pacini, N., Abete, M. C. \& Prearo, M. (2017). Oxidative stress and related biomarkers in cupric and cuprous chloride-treated rainbow trout. Environmental Science and Pollution Research, 24, 10205-10219. http:\\doi.org/10.1007/s11356-017-8651-z.

Engebretsen, K. V. T., Lunde, I. G., Strand, M. E., Waehre, A., Sjaastad, I., Marstein, H. S., Skrbic, B., Dahl, C. P., Askevold, E. T., Christensen, G., Bjørnstad, J. L. \& Tønnessen, T. (2013). Lumican is increased in experimental and clinical heart failure, and its production by cardiac fibroblasts is induced by mechanical and proinflammatory stimuli. The FEBS Journal, 280, 2382-2398. http:\\doi.org/10.1111/febs.12235.

Ferguson, H. W., Poppe, T. \& Speare, D. J. (1990). Cardiomyopathy in farmed Norwegian salmon. Diseases of Aquatic Organisms, 8, 225-231.

Flower, D. R. (1996). The lipocalin protein family: structure and function. Biochemical Journal, 318 ( Pt 1), 1-14. http:\\doi.org/10.1042/bj3180001.

Fritsvold, C., Kongtorp, R. T., Taksdal, T., Orpetveit, I., Heum, M. \& Poppe, T. T. (2009). Experimental transmission of cardiomyopathy syndrome (CMS) in Atlantic salmon Salmo salar. Diseases of Aquatic Organisms, 87, 225-34. http:\\doi.org/10.3354/dao02123.

Fritvold, C. (2016). Cardiomyopathy syndrome (CMS) In The Fish Health Report 2015, Hjeltnes, B., Walde, C.S., Bang-Jensen, B. \& Haukaas, A. (eds.). The Norwegian Veterinary Institute: Norway, p. 30-31.

Fritvold, C. \& Jensen, B. B. (2019). Cardiomyopathy syndrome (CMS) In The Health Situation in Norwegian Aquaculture 2018, Hjeltnes, B., Bang-Jensen, B., Bornø, G., Haukaas, A. \& Walde, C.S. (eds.). Norwegian Veterinary Institute: Norway, p. 52-55.

Garseth, A. H., Fritsvold, C., Svendsen, J. C., Bang Jensen, B. \& Mikalsen, A. B. (2018). Cardiomyopathy syndrome in Atlantic salmon Salmo salar L.: A review of the current state of knowledge. Journal of Fish Diseases, 41, 11-26. http:\\doi.org/10.1111/jfd.12735.

Geyer, P. E., Holdt, L. M., Teupser, D. \& Mann, M. (2017). Revisiting biomarker discovery by plasma proteomics. Molecular Systems Biology, 13, 942. http:\\doi.org/10.15252/msb.20156297. 
Götz, S., Garcia-Gomez, J. M., Terol, J., Williams, T. D., Nagaraj, S. H., Nueda, M. J., Robles, M., Talon, M., Dopazo, J. \& Conesa, A. (2008). High-throughput functional annotation and data mining with the Blast2GO suite. Nucleic Acids Res, 36, 3420-35. http:\\doi.org/10.1093/nar/gkn176.

Group, B. D. W. (2001). Biomarkers and surrogate endpoints: preferred definitions and conceptual framework. Clinical Pharmacology \& Therapeutics, 69, 89-95. http:\\doi.org/10.1067/mcp.2001.113989.

Haas, B., Serchi, T., Wagner, D. R., Gilson, G., Planchon, S., Renaut, J., Hoffmann, L., Bohn, T. \& Devaux, Y. (2011). Proteomic analysis of plasma samples from patients with acute myocardial infarction identifies haptoglobin as a potential prognostic biomarker. Journal of Proteomics, 75, 229-236.

http:\\doi.org/https://doi.org/10.1016/j.jprot.2011.06.028.

Haugland, O., Mikalsen, A. B., Nilsen, P., Lindmo, K., Thu, B. J., Eliassen, T. M., Roos, N., Rode, M. \& Evensen, O. (2011). Cardiomyopathy syndrome of atlantic salmon (Salmo salar L.) is caused by a double-stranded RNA virus of the Totiviridae family. Journal of Virology, 85, 5275-86. http:\\doi.org/10.1128/JVI.02154-10.

Hellman, N. E. \& Gitlin, J. D. (2002). Ceruloplasmin metabolism and function. Annual Review of Nutrition, 22, 43958. http:\\doi.org/10.1146/annurev.nutr.22.012502.114457.

Holme, I., Aastveit, A. H., Hammar, N., Jungner, I. \& Walldius, G. (2009). Haptoglobin and risk of myocardial infarction, stroke, and congestive heart failure in 342,125 men and women in the Apolipoprotein MOrtality RISk study (AMORIS). Annals of Medicine, 41, 522-532. http:\\doi.org/10.1080/07853890903089453.

Hourcade, D. E., Mitchell, L. M. \& Oglesby, T. J. (1998). A conserved element in the serine protease domain of complement factor B. Journal of Biological Chemistry, 273, 25996-6000.

http:\\doi.org/10.1074/jbc.273.40.25996.

Jain, S., Gautam, V. \& Naseem, S. (2011). Acute-phase proteins: As diagnostic tool. Journal of Pharmacy And Bioallied Sciences, 3, 118-127. http:\\doi.org/10.4103/0975-7406.76489.

Kemp, M., Donovan, J., Higham, H. \& Hooper, J. (2004). Biochemical markers of myocardial injury. British Journal of Anaesthesia, 93, 63-73. http:\\doi.org/10.1093/bja/aeh148.

Khan, A. A., Allemailem, K. S., Alhumaydhi, F. A., Gowder, S. J. T. \& Rahmani, A. H. (2020). The biochemical and clinical perspectives of lactate dehydrogenase: an enzyme of active metabolism. Endocrine, Metabolic \& Immune Disorders - Drug Targets 20, 855-868. http: IIdoi.org/10.2174/1871530320666191230141110.

Kikuchi, K., Holdway, J. E., Major, R. J., Blum, N., Dahn, R. D., Begemann, G. \& Poss, K. D. (2011). Retinoic acid production by endocardium and epicardium is an injury response essential for zebrafish heart regeneration. Developmental Cell, 20, 397-404. http:\\doi.org/10.1016/j.devcel.2011.01.010.

Klein, R., Nagy, O., Tóthová, C. \& Chovanová, F. (2020). Clinical and diagnostic significance of lactate dehydrogenase and its isoenzymes in animals. Veterinary Medicine International, 2020, 5346483. http:\\doi.org/10.1155/2020/5346483.

Kulkarni, P. A. \& Afshar-Kharghan, V. (2008). Anticomplement therapy. Biologics: targets \& therapy, 2, 671-685. http:\\doi.org/10.2147/btt.s2753. 
Kumar, S., Raman, R. P., Prasad, K. P., Srivastava, P. P., Kumar, S. \& Rajendran, K. V. (2018). Effects on haematological and serum biochemical parameters of Pangasianodon hypophthalmus to an experimental infection of Thaparocleidus sp. (Monogenea: Dactylogyridae). Experimental Parasitology, 188, 1-7. http:\/doi.org/https://doi.org/10.1016/j.exppara.2018.02.007.

Kumar, V., Abbas, A. K. \& Aster, J. C. (2014). Robbins \& Cotran pathologic basis of disease, Elsevier p. 88-89. Latimer, K. S. (2011). Duncan and Prasse's veterinary laboratory medicine: clinical pathology, Wiley-Blackwell p. 528.

Li, C., Tan, X. F., Lim, T. K., Lin, Q. \& Gong, Z. (2016). Comprehensive and quantitative proteomic analyses of zebrafish plasma reveals conserved protein profiles between genders and between zebrafish and human. Sci Rep, 6, 24329. http:\\doi.org/10.1038/srep24329.

Lindskog, S. (1997). Structure and mechanism of carbonic anhydrase. Pharmacology \& Therapeutics, 74, 1-20. http:\\doi.org/https://doi.org/10.1016/S0163-7258(96)00198-2.

Lippi, G., Mattiuzzi, C., Comelli, I. \& Cervellin, G. (2013). Glycogen phosphorylase isoenzyme BB in the diagnosis of acute myocardial infarction: a meta-analysis. Biochemia Medica, 23, 78-82.

http: \\doi.org/10.11613/bm.2013.010.

Liu, X. \& Collodi, P. (2002). Novel form of fibronectin from zebrafish mediates infectious hematopoietic necrosis virus infection. Journal of Virology, 76, 492-498. http:\\doi.org/10.1128/jvi.76.2.492-498.2002.

Liu, X., Zhao, Q. \& Collodi, P. (2003). A truncated form of fibronectin is expressed in fish and mammals. Matrix Biology, 22, 393-6. http:\\doi.org/10.1016/s0945-053x(03)00071-4.

Løvoll, M., Wiik-Nielsen, J., Grove, S., Wiik-Nielsen, C. R., Kristoffersen, A. B., Faller, R., Poppe, T., Jung, J., Pedamallu, C. S., Nederbragt, A. J., Meyerson, M., Rimstad, E. \& Tengs, T. (2010). A novel totivirus and piscine reovirus (PRV) in Atlantic salmon (Salmo salar) with cardiomyopathy syndrome (CMS). Virology Journal, 7, 309. http:\\doi.org/10.1186/1743-422X-7-309.

Mänttäri, M., Manninen, V., Huttunen, J. K., Palosuo, T., Ehnholm, C., Heinonen, O. P. \& Frick, M. H. (1994). Serum ferritin and ceruloplasmin as coronary risk factors. European Heart Journal, 15, 1599-603.

http:\\doi.org/10.1093/oxfordjournals.eurheartj.a060440.

Mayeux, R. (2004). Biomarkers potential uses and limitations. NeuroRx, 1, 182-188.

http:\\doi.org/10.1602/neurorx.1.2.182.

Mohammadzadeh, N., Lunde, I. G., Andenæs, K., Strand, M. E., Aronsen, J. M., Skrbic, B., Marstein, H. S., Bandlien, C., Nygård, S., Gorham, J., Sjaastad, I., Chakravarti, S., Christensen, G., Engebretsen, K. V. T. \& Tønnessen, T. (2019). The extracellular matrix proteoglycan lumican improves survival and counteracts cardiac dilatation and failure in mice subjected to pressure overload. Scientific Reports, 9, 9206. http:\\doi.org/10.1038/s41598-019-45651-9.

Nirala, N. R., Harel, Y., Lellouche, J.-P. \& Shtenberg, G. (2020). Ultrasensitive haptoglobin biomarker detection based on amplified chemiluminescence of magnetite nanoparticles. Journal of Nanobiotechnology, $18,6$. http:\\doi.org/10.1186/s12951-019-0569-9. 
Oliveira, R., McDonough, S., Ladewig, J. C. L., Soares, A. M. V. M., Nogueira, A. J. A. \& Domingues, I. (2013). Effects of oxytetracycline and amoxicillin on development and biomarkers activities of zebrafish (Danio rerio).

Environmental Toxicology and Pharmacology, 36, 903-912.

http:\\doi.org/https://doi.org/10.1016/j.etap.2013.07.019.

Pankov, R. \& Yamada, K. M. (2002). Fibronectin at a glance. Journal of Cell Science, 115, 3861-3863. http:\\doi.org/10.1242/jcs.00059.

Patel, S. (2017). A critical review on serine protease: Key immune manipulator and pathology mediator. Allergologia et Immunopathologia, 45, 579-591. http:\\doi.org/10.1016/j.aller.2016.10.011.

Poppe, T. T. \& Seierstad, S. L. (2003). First description of cardiomyopathy syndrome (CMS)-related lesions in wild Atlantic salmon Salmo salar in Norway. Diseases of Aquatic Organisms, 56, 87-88.

Ramasamy, S., Omnath, R., Rathinavel, A., Kannan, P., Dhandapany, P. S., Annapoorani, P., Balakumar, P., Singh, M., Ganesh, R. \& Selvam, G. S. (2006). Cardiac isoform of alpha 2 macroglobulin, an early diagnostic marker for cardiac manifestations in AIDS patients. AIDS, 20. http:\\doi.org/10.1097/01.aids.0000247122.97079.71.

Reunanen, A., Knekt, P. \& Aaran, R. K. (1992). Serum ceruloplasmin level and the risk of myocardial infarction and stroke. American Journal of Epidemiology, 136, 1082-1090. http:\\doi.org/10.1093/oxfordjournals.aje.a116573.

Ricklin, D., Hajishengallis, G., Yang, K. \& Lambris, J. D. (2010). Complement: a key system for immune surveillance and homeostasis. Nature Immunology, 11, 785-797. http:\\doi.org/10.1038/ni.1923.

Rodger, H. D., Murphy, T. M., Drinan, E. M. \& Rice, D. A. (1991). Acute skeletal myopathy in farmed Atlantic salmon Salmo salar. Diseases of Aquatic Organisms, 12, 17-23.

Rodger, H. D., McCleary, S. J. \& Ruane, N. M. (2014). Clinical cardiomyopathy syndrome in Atlantic salmon, Salmo salar L. Journal of Fish Diseases, 37, 935-939. http:\\doi.org/10.1111/jfd.12186.

Rojas, V., Morales-Lange, B., Avendaño-Herrera, R., Poblete-Morales, M., Tapia-Cammas, D., Guzmán, F., Marshall, S. H. \& Mercado, L. (2018). Detection of muscle-specific creatine kinase expression as physiological indicator for Atlantic salmon (Salmo salar L.) skeletal muscle damage. Aquaculture, 496, 66-72. http:\\doi.org/10.1016/j.aquaculture.2018.07.006.

Sahoo, P. K., Das, S., Mahapatra, K. D., Saha, J. N., Baranski, M., Ødegård, J. \& Robinson, N. (2013). Characterization of the ceruloplasmin gene and its potential role as an indirect marker for selection to Aeromonas hydrophila resistance in rohu, Labeo rohita. Fish \& Shellfish Immunology, 34, 1325-1334.

http:\\doi.org/10.1016/j.fsi.2013.02.020.

Saleh, M., Kumar, G., Abdel-Baki, A. A., Dkhil, M. A., El-Matbouli, M. \& Al-Quraishy, S. (2018). Quantitative shotgun proteomics distinguishes wound-healing biomarker signatures in common carp skin mucus in response to Ichthyophthirius multifiliis. Veterinary Research, 49, 37. http:\\doi.org/10.1186/s13567-018-0535-9.

Salte, R., Norberg, K., Ødegaard, O. R., Arnesen, J. A. \& Olli, J. J. (1993). Exotoxin-induced consumptive coagulopathy in Atlantic salmon, Salmo salar L.: inhibitory effects of exogenous antithrombin and a2- 
macroglobulin on Aeromonas salmonicida serine protease. Journal of Fish Diseases, 16, 425-435. http:\\doi.org/10.1111/j.1365-2761.1993.tb00876.x.

Shevchenko, A., Wilm, M., Vorm, O. \& Mann, M. (1996). Mass spectrometric sequencing of proteins from silverstained polyacrylamide gels. Analytical Chemistry, 68, 850-858. http:\ldoi.org/10.1021/ac950914h.

Smith, J. G. \& Gerszten, R. E. (2017). Emerging affınity-based proteomic technologies for large-scale plasma profiling in cardiovascular disease. Circulation, 135, 1651-1664.

http:\\doi.org/10.1161/CIRCULATIONAHA.116.025446.

Soman, S., Manju, C. S., Rauf, A. A., Indira, M. \& Rajamanickam, C. (2011). Role of cardiac isoform of alpha-2 macroglobulin in diabetic myocardium. Mol Cell Biochem, 350, 229-35. http:\\doi.org/10.1007/s11010-010-07024.

Sundby, A., Hemre, G.-I., Borrebaek, B., Christophersen, B. \& Blom, A. K. (1991). Insulin and glucagon family peptides in relation to activities of hepatic hexokinase and other enzymes in fed and starved Atlantic salmon (Salmo salar) and cod (Gadus morhua). Comparative Biochemistry and Physiology Part B: Comparative Biochemistry, 100, 467-470. http:\\doi.org/https://doi.org/10.1016/0305-0491(91)90205-R.

Taylor, G. K. \& Goodlett, D. R. (2005). Rules governing protein identification by mass spectrometry. Rapid Communications in Mass Spectrometry, 19, 3420-3420. http:\\doi.org/10.1002/rcm.2225.

Valenzuela-Muñoz, V., Boltaña, S. \& Gallardo-Escárate, C. (2017). Uncovering iron regulation with species-specific transcriptome patterns in Atlantic and coho salmon during a Caligus rogercresseyi infestation. Journal of Fish Diseases, 40, 1169-1184. http:\\doi.org/10.1111/jfd.12592.

Vuotikka, P., Ylitalo, K., Vuori, J., Väänänen, K., Kaukoranta, P., Lepojärvi, M. \& Peuhkurinen, K. (2003). Serum myoglobin/carbonic anhydrase III ratio in the diagnosis of perioperative myocardial infarction during coronary bypass surgery. Scandinavian Cardiovascular Journal, 37, 23-29. http:\\doi.org/10.1080/14017430310006992.

Wang, J., Karra, R., Dickson, A. L. \& Poss, K. D. (2013). Fibronectin is deposited by injury-activated epicardial cells and is necessary for zebrafish heart regeneration. Developmental Biology, 382, 427-435.

http:\/doi.org/https://doi.org/10.1016/j.ydbio.2013.08.012.

Weisel, J. W., Nagaswami, C., Woodhead, J. L., DeLa Cadena, R. A., Page, J. D. \& Colman, R. W. (1994). The shape of high molecular weight kininogen. Organization into structural domains, changes with activation, and interactions with prekallikrein, as determined by electron microscopy. Journal of Biological Chemistry, 269, 101006.

Wong, M. K. S. 2016. Subchapter 30A - Kininogen. In Handbook of Hormones, Takei, Y., Ando, H. \& Tsutsui, K. (Eds.) Ed. (p. 268-e30A-3). Chapter. Academic Press: San Diego. Available from:

http://www.sciencedirect.com/science/article/pii/B978012801028000180X

Wu, Q., Kuo, H. C. \& Deng, G. G. (2005). Serine proteases and cardiac function. Biochim Biophys Acta, 1751, 82-94. http:\\doi.org/10.1016/j.bbapap.2004.09.005. 
Xu, Y., Lin, H., Zhou, Y., Cheng, G. \& Xu, G. (2013). Ceruloplasmin and the extent of heart failure in ischemic and nonischemic cardiomyopathy patients. Mediators Inflamm, 2013, 348145. http:\\doi.org/10.1155/2013/348145.

Yndestad, A., Landrø, L., Ueland, T., Dahl, C. P., Flo, T. H., Vinge, L. E., Espevik, T., Frøland, S. S., Husberg, C., Christensen, G., Dickstein, K., Kjekshus, J., Øie, E., Gullestad, L. \& Aukrust, P. (2009). Increased systemic and myocardial expression of neutrophil gelatinase-associated lipocalin in clinical and experimental heart failure. European Heart Journal, 30, 1229-1236. http:\Idoi.org/10.1093/eurheartj/ehp088.

Yoshino, S., Fujimoto, K., Takada, T., Kawamura, S., Ogawa, J., Kamata, Y., Kodera, Y. \& Shichiri, M. (2019). Molecular form and concentration of serum a2-macroglobulin in diabetes. Scientific Reports, 9, 12927. http:\\doi.org/10.1038/s41598-019-49144-7.

Yousaf, M. N. \& Powell, M. D. (2012). The effects of heart and skeletal muscle inflammation and cardiomyopathy syndrome on creatine kinase and lactate dehydrogenase levels in Atlantic salmon (Salmo salarL.). Scientific World Journal, 2012, 741302. http:\\doi.org/10.1100/2012/741302.

Zamanova, S., Shabana, A. M., Mondal, U. K. \& Ilies, M. A. (2019). Carbonic anhydrases as disease markers. Expert Opinion on Therapeutic Patents, 29, 509-533. http:\\doi.org/10.1080/13543776.2019.1629419.

Zhou, B., Zhou, Z., Chen, Y., Deng, H., Cai, Y., Rao, X., Yin, Y. \& Rong, L. (2020). Plasma proteomics-based identification of novel biomarkers in early gastric cancer. Clinical Biochemistry, 76, 5-10.

http:\\doi.org/10.1016/j.clinbiochem.2019.11.001.

Zhu, Y. \& Gius, D. (2018). Glycogen phosphorylase: A novel biomarker in doxorubicin-induced cardiac injury. Clinical Cancer Research, 24, 1516-1517. http:\\doi.org/10.1158/1078-0432.CCR-17-3276.

Ziakas, A., Gavrilidis, S., Souliou, E., Giannoglou, G., Stiliadis, I., Karvounis, H., Efthimiadis, G., Mochlas, S., Vayona, M. A., Hatzitolios, A., Savopoulos, C., Pidonia, I. \& Parharidis, G. (2009). Ceruloplasmin is a better predictor of the long-term prognosis compared with fibrinogen, CRP, and IL-6 in patients with severe unstable angina. Angiology, 60, 50-9. http: \\doi.org/10.1177/0003319708314249

\section{Tables}

Table 1 - Fish disease status assessed by gross pathology, histology and RT-qPCR (heart and serum) of each individual sample pooled to be analysed by proteomics. 


\begin{tabular}{|c|c|c|c|c|}
\hline \multirow[t]{2}{*}{ Proteomic samples } & \multicolumn{2}{|l|}{ Pathology } & \multicolumn{2}{|c|}{$\begin{array}{l}\text { RT-qPCR } \\
\text { (Ct values) }\end{array}$} \\
\hline & Gross signs & Histology & Heart & Serum \\
\hline \multirow[t]{4}{*}{ CMS- 1} & Neg & Neg & $\S$ & $\S$ \\
\hline & Neg & $\mathrm{Neg}$ & $\S$ & $\S$ \\
\hline & Neg & $\mathrm{Neg}$ & $\S$ & $\S$ \\
\hline & Neg & Neg & $\S$ & $\S$ \\
\hline \multirow[t]{4}{*}{ CMS- 2} & Neg & Neg & $\S$ & $\S$ \\
\hline & Neg & Neg & $\S$ & $\S$ \\
\hline & Neg & Neg & $\S$ & $\S$ \\
\hline & Neg & Neg & $\S$ & $\S$ \\
\hline \multirow[t]{4}{*}{ CMS- 3} & Neg & Neg & $\S$ & $\S$ \\
\hline & $\mathrm{Neg}$ & Neg & $\S$ & $\S$ \\
\hline & Neg & Neg & $\S$ & $\S$ \\
\hline & Neg & Neg & $\S$ & $\S$ \\
\hline \multirow[t]{4}{*}{$\mathrm{CMS}+1$} & Pos & NP & NP & 28.5 \\
\hline & Pos & NP & NP & 30.3 \\
\hline & Pos & NP & NP & 30.8 \\
\hline & Pos & NP & NP & 30.1 \\
\hline \multirow[t]{4}{*}{$\mathrm{CMS}+2$} & Pos & NP & NP & 33.2 \\
\hline & Pos & NP & NP & 34.0 \\
\hline & Pos & NP & NP & 29.9 \\
\hline & Pos & NP & NP & 31.6 \\
\hline \multirow[t]{4}{*}{$\mathrm{CMS}+3$} & Pos & Pos & 15.6 & 31.3 \\
\hline & Pos & Pos & 17.7 & 30.2 \\
\hline & Pos & Pos & 18.3 & $\S$ \\
\hline & Pos & Pos & 15.7 & 30.8 \\
\hline
\end{tabular}

NP - not performed

$\S$ negative since the RT-qPCR result is "not detemined" 
Table 2 - Thirty seven protein sequences unique to cardiomyopathy syndrome-infected Atlantic salmon sera (CMS+), corresponding number of peptides and percentage of sequence cover (SC \%) for three CMS+ sample pools ( $n=4$ fish per pool). 


\begin{tabular}{|c|c|c|c|c|c|c|c|c|}
\hline \multirow[b]{2}{*}{ Accession } & & \multirow{2}{*}{$\begin{array}{l}\mathrm{MW} \\
{[\mathrm{kDa}]}\end{array}$} & \multicolumn{2}{|l|}{ Infected 1} & \multicolumn{2}{|l|}{ Infected 2} & \multicolumn{2}{|l|}{ Infected 3} \\
\hline & & & \#Peptides & $\begin{array}{l}\mathrm{SC} \\
{[\%]}\end{array}$ & \#Peptides & $\begin{array}{l}\mathrm{SC} \\
{[\%]}\end{array}$ & \#Peptides & $\begin{array}{l}\mathrm{SC} \\
{[\%]}\end{array}$ \\
\hline XP_014069247.1 & $\begin{array}{l}\text { Alpha-2- } \\
\text { macroglobulin } \\
\text { like }\end{array}$ & 105.2 & 17 & 26.5 & 16 & 29.2 & 16 & 25.8 \\
\hline XP_014057055.1 & $\begin{array}{l}\text { Apolipoprotein } \\
\text { Eb-like }\end{array}$ & 35.6 & 6 & 29.7 & 8 & 34.5 & 8 & 30.1 \\
\hline XP_014011065.1 & $\begin{array}{l}\text { Apolipoprotein } \\
\text { Eb-like }\end{array}$ & 31.1 & 4 & 22.9 & 11 & 48.4 & 9 & 40.0 \\
\hline NP_001158744.1 & $\begin{array}{l}\text { Beta-2- } \\
\text { glycoprotein } 1 \\
\text { precursor }\end{array}$ & 129.2 & 4 & 18.6 & 2 & 7.1 & 7 & 27.4 \\
\hline NP_001133769.1 & $\begin{array}{l}\text { Carbonic } \\
\text { anhydrase-like }\end{array}$ & 28.6 & 5 & 28.5 & 7 & 43.5 & 7 & 33.1 \\
\hline XP_013979099.1 & Ceruloplasmin & 38.8 & 18 & 18.6 & 26 & 27.4 & 15 & 17.3 \\
\hline NP_001133188.1 & $\begin{array}{l}\text { Creatine kinase } \\
\text { M-type }\end{array}$ & 42.9 & 9 & 30.7 & 13 & 41.7 & 7 & 31.2 \\
\hline XP_013984632.1 & Cofilin-2-like & 18.7 & 3 & 25.1 & 5 & 44.3 & 4 & 37.1 \\
\hline XP_014051546.1 & $\begin{array}{l}\text { Complement } \\
\text { factor B-like }\end{array}$ & 86.8 & 7 & 14.0 & 11 & 19.9 & 7 & 14.8 \\
\hline NP_001135172.1 & Enolase & 47.2 & 33 & 68.7 & 38 & 64.1 & 28 & 51.8 \\
\hline XP_014012275.1 & $\begin{array}{l}\text { Fibrinogen beta } \\
\text { chain-like }\end{array}$ & 54.9 & 18 & 40.9 & 19 & 40.5 & 29 & 48.1 \\
\hline XP_014050741.1 & $\begin{array}{l}\text { Fibrinogen } \\
\text { gamma chain } \\
\text { like }\end{array}$ & 48.6 & 17 & 38.9 & 16 & 37.3 & 23 & 47.1 \\
\hline XP_014061843.1 & $\begin{array}{l}\text { Fibrinogen } \\
\text { alpha chain-like }\end{array}$ & 79.9 & 11 & 18.4 & 6 & 8.5 & 9 & 12.6 \\
\hline XP_014021181.1 & Fibronectin-like & 246.9 & 5 & 3.4 & 4 & 2.6 & 4 & 2.6 \\
\hline NP_001133181.1 & $\begin{array}{l}\text { Fructose- } \\
\text { bisphosphate } \\
\text { aldolase A }\end{array}$ & 39.5 & 26 & 63.1 & 28 & 65.0 & 23 & 61.2 \\
\hline NP_001133122.1 & $\begin{array}{l}\text { Glycogen } \\
\text { phosphorylase, } \\
\text { muscle form }\end{array}$ & 97.4 & 15 & 21.2 & 13 & 23.2 & 5 & 8.5 \\
\hline XP_014019196.1 & $\begin{array}{l}\text { Haptoglobin - } \\
\text { like }\end{array}$ & 34.8 & 31 & 68.0 & 29 & 68.7 & 28 & 66.5 \\
\hline NP_001265947.1 & $\begin{array}{l}\text { Haemoglobin } \\
\text { subunit beta } 1\end{array}$ & 16.0 & 18 & 89.8 & 18 & 89.8 & 17 & 89.8 \\
\hline XP_014048454.1 & $\begin{array}{l}\text { Haemoglobin } \\
\text { subunit beta } 1 \text { - } \\
\text { like }\end{array}$ & 16.0 & 17 & 89.8 & 17 & 89.8 & 16 & 89.8 \\
\hline
\end{tabular}




\begin{tabular}{|c|c|c|c|c|c|c|c|c|}
\hline XP_014048453.1 & $\begin{array}{l}\text { Haemoglobin } \\
\text { subunit alpha }\end{array}$ & 15.9 & 11 & 62.2 & 11 & 57.3 & 7 & 57.3 \\
\hline XP_014048452.1 & $\begin{array}{l}\text { Haemoglobin } \\
\text { subunit alpha-4 }\end{array}$ & 15.2 & 9 & 62.2 & 10 & 62.2 & 11 & 57.3 \\
\hline XP_014047100.1 & $\begin{array}{l}\text { Haemoglobin } \\
\text { subunit beta }\end{array}$ & 10.1 & 6 & 63.4 & 7 & 63.4 & 7 & 63.4 \\
\hline XP_014046901.1 & Histone $\mathrm{H} 4$ & 11.4 & 5 & 40.8 & 5 & 40.8 & 6 & 50.5 \\
\hline XP_014063047.1 & $\begin{array}{l}\text { L-lactate } \\
\text { dehydrogenase } \\
\text { B chain }\end{array}$ & 36.3 & 2 & 9.0 & 2 & 9.9 & 9 & 35.0 \\
\hline XP_014037121.1 & Lipocalin-like & 20.1 & 4 & 30.4 & 6 & 34.3 & 5 & 30.4 \\
\hline XP_014009124.1 & Lumican-like & 38.1 & 9 & 27.2 & 9 & 28.1 & 7 & 21.3 \\
\hline XP_013991158.1 & $\begin{array}{l}\text { Keratin type II } \\
\text { cytoskeletal } \\
\text { cochleal-like }\end{array}$ & 58.2 & 2 & 4.1 & 3 & 4.1 & 3 & 4.1 \\
\hline XP_014024862.1 & Kininogen-1-like & 41.5 & 5 & 20.0 & 4 & 20.0 & 5 & 25.6 \\
\hline XP_014049817.1 & $\begin{array}{l}\text { Mannose- } \\
\text { binding protein } \\
\text { C-like }\end{array}$ & 22.8 & 3 & 16.7 & 5 & 20.5 & 3 & 16.7 \\
\hline XP_014049624.1 & $\begin{array}{l}\text { Parvalbumin } \\
\text { beta } 1\end{array}$ & 11.9 & 7 & 66.1 & 5 & 48.6 & 5 & 48.6 \\
\hline NP_001135161.1 & $\begin{array}{l}\text { 2-peptidylprolyl } \\
\text { isomerase }\end{array}$ & 17.5 & 3 & 20.7 & 6 & 29.3 & 7 & 42.1 \\
\hline NP_001135175.1 & $\begin{array}{l}\text { Pyruvate kinase } \\
\text { PKM-like }\end{array}$ & 58.3 & 13 & 31.5 & 17 & 38.7 & 9 & 20.4 \\
\hline NP_001266041.1 & $\begin{array}{l}\text { Serine protease- } \\
\text { like protein }\end{array}$ & 23.7 & 8 & 55.3 & 8 & 62.6 & 8 & 52.5 \\
\hline XP_014011142.1 & $\begin{array}{l}\text { Sex hormone- } \\
\text { binding globulin }\end{array}$ & 43.7 & 13 & 43.6 & 6 & 22.2 & 4 & 12.6 \\
\hline XP_014013823.1 & $\begin{array}{l}\text { Retinol-binding } \\
\text { protein 4-B }\end{array}$ & 21.9 & 10 & 49.5 & 9 & 49.5 & 12 & 69.8 \\
\hline XP_014034361.1 & $\begin{array}{l}\text { Retinol-binding } \\
\text { protein } 4 \\
\text { isoform X1 }\end{array}$ & 21.9 & 7 & 43.8 & 7 & 43.8 & 11 & 43.8 \\
\hline XP_014022930.1 & $\begin{array}{l}\text { Triosephosphate } \\
\text { isomerase B }\end{array}$ & 26.5 & 18 & 81.8 & 15 & 63.6 & 16 & 71.7 \\
\hline
\end{tabular}

Table 3 - Ten protein sequences unique to cardiomyopathy syndrome negative Atlantic salmon sera (CMS-), corresponding number of peptides and percentage of sequence cover (SC \%) for three CMS- sample pools $(n=4$ fish per pool). 


\begin{tabular}{llllllll} 
& & \multicolumn{2}{c}{ Non-infected 1 } & \multicolumn{2}{c}{ Non-infected 2 } & \multicolumn{2}{c}{ Non-infected 3 } \\
\hline Accession no. & & \#Peptides & $\begin{array}{c}\text { SC } \\
{[\%]}\end{array}$ & \#Peptides & $\begin{array}{c}\text { SC } \\
{[\%]}\end{array}$ & \#Peptides & $\begin{array}{c}\text { SC } \\
{[\%]}\end{array}$ \\
\hline XP_013999412.1 & $\begin{array}{l}\text { Apolipoprotein B-100 } \\
\text { isoform X4 }\end{array}$ & 69 & 26.4 & 68 & 24.8 & 72 & 31.5 \\
\hline XP_013979020.1 & Complement factor H-like & 12 & 34.5 & 12 & 37.1 & 16 & 53.3 \\
\hline XP_014018408.1 & Fucolectin-6-like & 8 & 42.0 & 6 & 21.8 & 9 & 39.6 \\
\hline XP_014059764.1 & $\begin{array}{l}\text { Haemoglobin subunit } \\
\text { beta-1-like }\end{array}$ & 13 & 72.8 & 12 & 72.8 & 15 & 72.8 \\
\hline XP_013979096.1 & $\begin{array}{l}\text { Histidine-rich } \\
\text { glycoprotein-like }\end{array}$ & 21 & 40.6 & 22 & 40.4 & 27 & 41.2 \\
\hline XP_014005720.1 & Ladderlectin-like & 5 & 33.9 & 9 & 53.2 & 5 & 39.8 \\
\hline NP_001117052.1 & Lectin C type receptor B & 5 & 18.8 & 6 & 22.9 & 9 & 38.3 \\
\hline XP_013999800.1 & LEG1 homolog & 5 & 17.0 & 6 & 19.0 & 10 & 33.5 \\
\hline XP_014060522.1 & Protein LEG1 homolog & 5 & 12.1 & 8 & 17.4 & 9 & 24.0 \\
\hline XP_014019752.1 & $\begin{array}{l}\text { Type-4 ice-structuring } \\
\text { protein LS-12-like }\end{array}$ & 5 & 38.6 & 6 & 44.8 & 6 & 54.5 \\
& & & & & & &
\end{tabular}

\section{Figures}

\begin{tabular}{|c|c|c|}
\hline Leakage enzymes & Host reaction & $\begin{array}{l}\text { Regeneration/ } \\
\text { Remodelling }\end{array}$ \\
\hline $\begin{array}{c}\text { Creatine kinase } \\
\text { Lactate dehydrogenase } \\
\text { Glycogen } \\
\text { phosphorylase } \\
\text { Carbonic anhydrase }\end{array}$ & $\begin{array}{c}\text { Haptoglobin } \\
\text { Fibrinogen } \\
\text { Kininogen }^{\S} \\
\alpha 2 \text {-macroglobulin } \\
\text { Ceruloplasmin }^{\S} \\
\text { Complement factor } \mathrm{B}^{+} \\
\text {Serine protease-like } \\
\text { Kininogen }\end{array}$ & $\begin{array}{l}\text { Fibronectin } \\
\text { Lumican } \\
\text { Retinol-binding } \\
\text { Lipocalin }\end{array}$ \\
\hline
\end{tabular}

\section{Figure 1}

Protein profiles of sera sampled from Atlantic salmon (Salmo salar L.): consistent with cardiomyopathy syndrome (CMS+) and negative for cardiomyopathy syndrome (CMS-), run on a 12\% NuPAGE Bis-Tris SDS-PAGE gel and 
stained with Coomassie blue. CMS+ pools diluted two fold ( $\mathrm{n}=4$ fish per pool) are in Lane 2 - CMS+1; Lane 3 CMS+2; Lane 4 - CMS+3. CMS- pools diluted 1:16 ( $\mathrm{n}=4$ fish per pool) are in Lane $5-\mathrm{CMS}-1$; Lane $6 \mathrm{CMS}-2$ and Lane 7 - CMS-3. Lane 1 is molecular weight (Mwt).

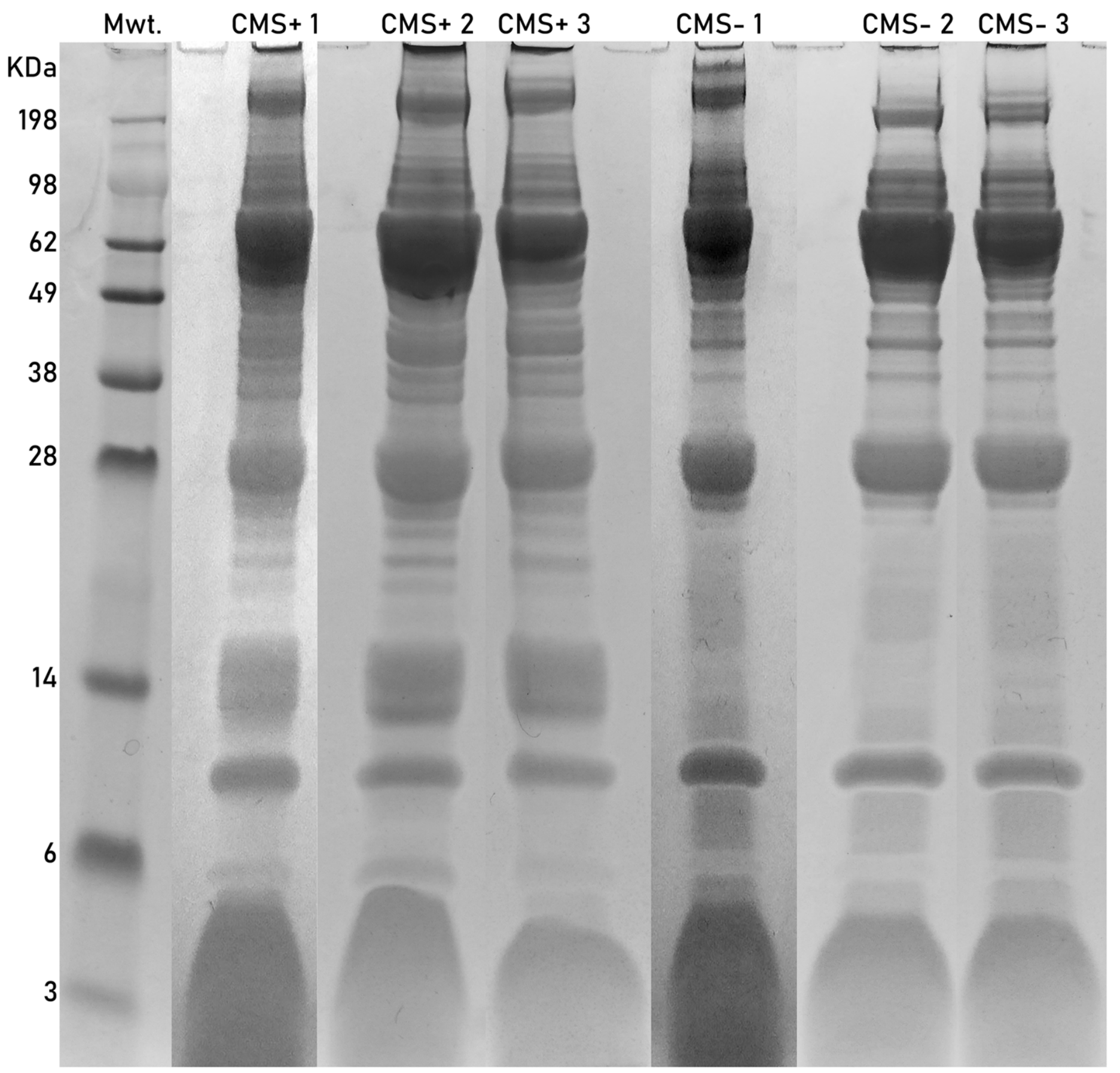

\section{Figure 2}

Summary of candidate biomarkers from a list of proteins unique to CMS+ sera pools ( 4 fish/pool), listed by broad type. *acute phase response proteins; +complement proteins.

\section{Supplementary Files}


This is a list of supplementary files associated with this preprint. Click to download.

- supplementeddata.xIsx 